\title{
PTPN1 Gene
}

National Cancer Institute

\section{Source}

National Cancer Institute. PTPN1 Gene. NCI Thesaurus. Code C24705.

This gene plays a role in the regulation of insulin signaling and inhibition of cell growth. 